\title{
Pseudo High-Throughput Development and Optimization of the Electrochemical Oxidation of Sensitive Propargylic Benzylic Alcohols
}

\author{
Chad E. Hatch, ${ }^{*}$ Maxwell I. Martin, ${ }^{\ddagger}$ Danielle J. Beam, Glenn P. A. Yap, Matthew J. Von Bargen, Joel \\ Rosenthal,* and William J. Chain* \\ Department of Chemistry \& Biochemistry, University of Delaware, Newark, DE 19716. \\ Electrochemistry, Electrochemical Mediators, Synthesis, Oxidation, Resveratrol Natural Products, Pauciflorols.
}

\begin{abstract}
The electrochemical oxidation of sensitive propargylic benzylic alcohols having varying substituents is reported. The thermal oxidation of propargylic benzylic alcohols presents an acute challenge in the synthesis of complex molecules and various traditional oxidation methods proceed with low efficiency or not at all. We describe the convenient preparation and characterization of $N$-hydroxytetrafluorophthalimide (TFNHPI) and a practical, green electrochemical oxidation protocol that employs TFNHPI as a stable, efficient electrochemical mediator. The electrochemical method employing TFNHPI to oxidize propargylic benzylic alcohols was developed and optimized in pseudo high-throughput fashion using a bank of inexpensive two-electrode power supplies. The electrochemical oxidation of propargylic benzylic alcohol was also leveraged to develop efficient synthetic pathways to prepare gram quantities of resveratrol natural products such as the pauciflorols.
\end{abstract}

The oxidation of alcohols to the corresponding carbonyl compound is ostensibly a simple $2 e^{-} / 2 \mathrm{H}^{+}$process. Conventional oxidation methods typically employ high valent metals or other electron-deficient species as electron sinks, and mechanistically these reactions all consist of an elimination type mechanism in which a proton is removed and two electrons are transferred to a stoichiometric electrophile. ${ }^{1}$ Great advances in traditional oxidation chemistry have driven the field of organic synthesis to the great modern success it is today, allowing the oxidation of many alcohols to the corresponding aldehyde, ketone, and carboxylic acid equivalents under a variety of reaction conditions.

Highly genotoxic and carcinogenic hexavalent chromiumbased (i.e., Cr(VI)) oxidants such as Jones' reagent, ${ }^{2}$ or gentler anhydrous homologs such as the Collins reagent ${ }^{3}$ have been routinely employed for oxidative operations for decades. Additionally, a variety of electron-deficient species employing metals, metalloids, and non-metals have offered myriad alternative approaches and a library of highly selective reagents and reactions that can be tailored to specific applications.

Despite this body of work, many thermal oxidations of organic compounds remain a challenge. For example, several recent synthetic efforts make this challenge plain, with propargylic benzylic alcohol substrates undergoing oxidation via typical thermal protocols (Jones' reagent, ${ }^{+}$manganese(IV) oxide, Dess-Martin periodinane, ${ }^{6}$ or photochemical processes 7 ) with low efficiency (Scheme 1). More electron-deficient substrates such as $\mathbf{4}$ are particularly intransigent. Illustrative of this point, we treated alcohol 4 with several equivalents of $\mathrm{MnO}_{2}$ in $\mathrm{CH}_{2} \mathrm{Cl}_{2}$ at reflux, which only returned the starting material unchanged.

Electrochemical organic transformations are increasingly attractive means that can be leveraged to prepare small molecules and fine chemicals. With proper reaction design, electrosynthetic methods can be inherently efficient, and replace exogenous oxidants or reductants with heterogenous electrodes that directly deliver the oxidizing (or reducing) equivalents needed to promote chemical transformations. ${ }^{8-17}$ In the last decade, electrochemical methods have gained increased attention in synthesis owing to the growing array of transformations that such methods can promote. Moreover, electrochemistry can also

offer

Scheme 1. Oxidation Methods for Propargylic Benzylic Alcohols.

synthetic solutions for which there are no practical thermal reaction equivalents ${ }^{18-21}$ and the development and adoption of more sustainable and environmentally friendly methods are critical to the evolution of modern synthetic organic chemistry.22

Certain organic molecules can be employed as electrochemical mediators ${ }^{23}$ that facilitate oxidative chemistry by cleanly undergoing single electron oxidations at conveniently applied potentials. Upon oxidation, such mediators are converted to a radical, cation, or other electron-deficient intermediate that can in turn induce an oxidative process on substrates of interest. Organic molecules, such as $\mathrm{TEMPO}^{24}$ that serve various roles in thermal radical chemistries have inspired the development of such electrochemical mediators and have been described in the context of electrochemical oxidative chemistry since the early $1980 \mathrm{~s}^{2}$

$N$-Hydroxyphthalimides (NHPIs) have been employed as particularly powerful electrochemical mediators in the oxidation of isolongifolene, cedrene, dehydroepianrosterone, and other terpenoid and steroidal natural products. ${ }^{26}$ In recent work showcasing the regioselectivity that electrochemically mediated oxidations can offer, Baran and coworkers, demonstrated that the more electron-deficient $N$-hydroxytetrachlorophthalimide (TCNHPI) served to mediate the electrochemical oxidation of various allylic substrates, culminating in the oxidations of nootkatone (from valencene) and cyperone. ${ }^{26}$ Key to this success was the generation of a considerably more reactive electron-deficient tetrachlorophthalimido $N$-oxyl radical, facilitating the oxidation of valencene to nootkatone in $77 \%$ yield (vs 56\% yield employing the unhalogenated NHPI). Studies on the influence of halogen substitution on the NHPI-mediated oxidation chemistry of hydrocarbons revealed a delicate balance between the NO- $\mathrm{H}$ bond strength and the stability of the putative $N$-oxyl radical intermediates. ${ }^{27}$ The reader is directed to an extensive study of NHPI electrochemical mediators that was recently reported and which elegantly describes the reaction conditions that facilitate maximum synthetic utility. ${ }^{28}$

Despite the community's emphasis on NHPI type mediators for oxidative electrochemistry, $N$-Hydroxytetrafluorophthalimide (TFNHPI) has been comparatively ignored within this arena. This omission was surprising to us, as TFNHPI might be expected to facilitate more challenging oxidations owing to the four electron-withdrawing fluorines on the thalimide backbone. One reason for this omission may be early reports that characterized TFNHPI as thermally unstable. ${ }^{29}$ In contrast to those earlier studies, however, we now report TFNHPI to be an indefinitely bench stable, easily handled crystalline solid amenable to characterization by single crystal X-ray diffraction (see Supporting Information (SI)). We also show that TFNHPI can serve as a more effective electrochemical mediator than NHPI or TCNHPI in certain applications. In particular, we demonstrate the utility of TFNHPI in electrochemically mediating the highly challenging oxidation of sensitive propargylic benzylic alcohols, which typically only undergo thermal oxidation reactions in poor yields accompanied by decomposition or other undesired side reactions. ${ }^{30-32}$

TFNHPI was first described by Coe and coworkers in 1967 during studies of the reactivity of phthalic acid derivatives..$^{29}$ Electrochemical studies employing this material have been very limited. $^{33}$ We report here a practical preparation of TFNHPI, and that TFNHPI can serve as an efficient and robust electrochemical mediator to solve the problem of oxidation of sensitive propargylic benzylic alcohols (1). We cleanly generate the corresponding ketones (2) in excellent yield, greatly outperforming thermal oxidation reactions, which typically require large excesses of oxidant, prolonged reaction times, and generate stoichiometric amounts of waste products that are both toxic and environmentally hazardous.

We can generate TFNHPI in five-gram $(17 \mathrm{mmol})$ lots in $75 \%$ overall yield from commercial materials via a modified procedure based on the work of Coe (see Supporting Information for details). Cyclic voltammograms recorded for TFNHPI in $\mathrm{CH}_{3} \mathrm{CN}$ containing $0.1 \mathrm{M}$ tetra- $n$-butylammonium hexafluorophosphate $\left(\mathrm{TBAPF}_{6}\right)$ as supporting electrolyte revealed that this compound undergoes an oxidation event at $E \sim$ $2.4 \mathrm{~V}$ (vs. $\mathrm{Ag} / \mathrm{AgCl}$ - note that all potentials herein are reported relative to this reference electrode), which is considerably more oxidizing than previously reported potentials of NHPI $(793 \mathrm{mV}$ vs. $\mathrm{Ag} / \mathrm{AgCl})$ and TCNHPI $(870 \mathrm{mV}$ vs. $\mathrm{Ag} / \mathrm{AgCl}){ }^{5}$ Cyclic voltammograms and other electrochemical data recorded for TFNHPI are reproduced as Figures S1-S4 in the Supporting Information.

Table 1. Optimization of electrochemical oxidation conditions. ${ }^{\mathrm{a}}$



\begin{tabular}{ccccc} 
Entry & $\begin{array}{c}\text { Mediator } \\
(\text { mol\%) }\end{array}$ & Peroxide (equiv) & $\begin{array}{c}\text { Time } \\
(\mathrm{h})\end{array}$ & $\begin{array}{c}\text { Yield } \\
\%\end{array}$ \\
\hline 1 & 20 & 10 & 5 & $77 \%$ \\
2 & 10 & 10 & 5 & $75 \%$ \\
3 & 5 & 10 & 5 & $71 \%$ \\
4 & 2.5 & 10 & 3 & $84 \%$ \\
5 & 0 & 10 & 3 & $39 \%$ \\
6 & 2.5 & 7.5 & 3 & $44 \%$ \\
7 & 2.5 & 2.5 & 3 & $24 \%$ \\
8 & 2.5 & 1.25 & 3 & $16 \%$ \\
9 & 2.5 & 0 & 27 & $\mathrm{NR}$ \\
$10^{\mathrm{b}}$ & 2.5 & 10 & 5 & $45 \% \mathrm{c}$ \\
$11^{\mathrm{d}}$ & 2.5 & 10 & 5 & $60 \%{ }^{\mathrm{c}}$
\end{tabular}

${ }^{\mathrm{a}}$ General reaction conditions: $1.0 \mathrm{mmol}$ alcohol, $0.1 \mathrm{M} \mathrm{TBAPF}_{6}$, 10.0 equiv. $5.5 \mathrm{M} t$-BuOOH in decane, RVC electrodes. ${ }^{\mathrm{b}} \mathrm{TCNHPI}$ mediator. 'Product obtained as an inseparable mixture with multiple unidentified contaminants. ${ }^{\mathrm{d}}$ NHPI mediator.

To test the ability of TFNHPI to serve as an electrochemical mediator for oxidation of propargylic benzylic alcohols, constant potential electrolysis (CPE) experiments were carried out using a conventional three electrode configuration in a single compartment electrolysis cell containing 1-phenyl-2-propyn-1ol (1), $20 \mathrm{~mol} \%$ TFNHPI, 10 equivalents $5.5 \mathrm{M}$ tert-butyl hydroperoxide in decane, $10 \mathrm{~mL}$ acetonitrile, and $0.1 \mathrm{M} \mathrm{TBAPF}_{6}$. Both the anode and cathode were comprised of reticulated vitreous carbon (i.e., $\mathrm{RVC}=$ carbon foam). The working electrode (i.e., the anode) was poised at $E_{a p p}=2.4 \mathrm{~V}$ versus $\mathrm{Ag} / \mathrm{AgCl}$ and over the course of the reaction, the full cell potential (i.e., the potential difference between anode and cathode) was measured to be $E_{\text {cell }} \sim 3.5 \mathrm{~V}$. Under these electrolytic conditions, oxidation 
of alcohol 1 to ketone 2 was completed in over 75\% over the course of 5 hours.

By noting the full cell potential under the CPE, we were able to optimize the loading of electrochemical mediator (TFNHPI) and co-oxidant in pseudo high throughput fashion by using an array of ten inexpensive commercially available power supplies (see Figure S1 in SI). By using power supplies (as opposed to a potentiostat), we were able to drive electrolysis experiments using a more convenient two electrode configuration while maintaining the potential difference of $E_{\text {cell }}=3.5 \mathrm{~V}$ across anode and cathode. These electrolyses also employed the reticulated carbon foam anodes and cathodes and could be easily carried out open to atmosphere in disposable $15 \mathrm{~mL}$ falcon tubes with a simple glass microscope slide serving as a physical barrier to prevent the anode and cathode from contacting each other.

Initial electrolysis screens for the oxidation of $\mathbf{1}$ to $\mathbf{2}$ were conducted with $70 \%$ aqueous tert-butyl hydroperoxide $(t \mathrm{Bu}-$ $\mathrm{OOH}$ ), however, 5.5 $\mathrm{M} t \mathrm{Bu}-\mathrm{OOH}$ in decane solution was ultimately determined to be preferable to minimize the moisture content of the reaction mixture. Optimization of the reaction began with loading of TFNHPI (Table 1) starting with $20 \mathrm{~mol} \%$ mediator with model substrate 1 (i.e., 1-phenyl-2-propyn-1-ol) and excess (10 equiv) $t \mathrm{Bu}-\mathrm{OOH}$, which afforded the desired propargyl phenone $\mathbf{2}$ in $77 \%$ yield after a 5 h electrolysis at $E_{\text {cell }}$ $=3.5 \mathrm{~V}$.

We found reduction to $2.5 \mathrm{~mol} \%$ TFNHPI with 10 equiv of peroxide co-oxidant afforded clean conversion of starting alcohol 1 to propargyl phenone 2 in just three hours (40\% shorter reaction time than initially) with a boost to $84 \%$ isolated yield (Table 1, entry 4). In control experiments in which TFNHPI was excluded from the electrolysis cell conversion of alcohol 1 to ketone 2 dropped significantly (39\% isolated yield over the course of a 3 h electrolysis, Table 1 , entry 5). Thus, the fluorinated $N$-hydroxyphthalimide is indeed necessary for the observed oxidation to proceed cleanly and at a reasonable rate. We presume that the electrochemical homolysis of the $\mathrm{O}-\mathrm{H}$ bond of $t \mathrm{Bu}-\mathrm{OOH}{ }^{34}$ facilitates a small amount of background oxidation of $\mathbf{1}$ to $\mathbf{2}$ that is observed in the absence of TFNHPI.

Further reaction optimization determined that 10 equiv of 5.5 $\mathrm{M} t \mathrm{Bu}-\mathrm{OOH}$ resulted in the highest isolated yield of ketone 2 at $84 \%$, as reducing the loading of peroxide resulted in decrease yields of 2 (Table 1, entries 4, 6-8). Not surprisingly, control experiment excluding the $t \mathrm{Bu}-\mathrm{OOH}$ from the electrolysis solution resulted in no ketone product being produced over a $27-$ hour period with the starting alcohol recovered unchanged (Table 1, entry 9). NHPI and TCNHPI were also examined under our optimized reaction conditions, and though products were formed, we were unable to purify the ketone product when employing the more electron rich phthalimides. Under the electrolysis conditions employed in this work, the NHPI and TCNHPI mediators suffered from unproductive background decomposition reactions and fouled the RVC electrodes, rendering them inactive for further oxidative chemistry (Table 1, entries 10 and 11).

Having optimized the electrolysis conditions, we turned our attention to assessing substrate scope for the electrochemical oxidation reaction of Scheme 1. The electrochemical oxidation of propargylic benzylic alcohols tolerates a variety of electronrich and electron-poor substrates, however substrates sensitive to unproductive electrochemical reduction require the use of a divided cell (Scheme 2) to circumvent unwanted side reactions at the cathode. For example, substrates containing aromatic ethers and nitro groups are successfully oxidized to the corresponding ketones $(\mathbf{7}, \mathbf{1 1}, \mathbf{5}$, and 14$)$ in a divided cell that prevents substrate migration to the cathodic side of the electrolysis cell. In general, we find that implementation of the electrochemical

Scheme 2. Electrochemical Oxidation of Sensitive Alcohols. ${ }^{\text {a }}$
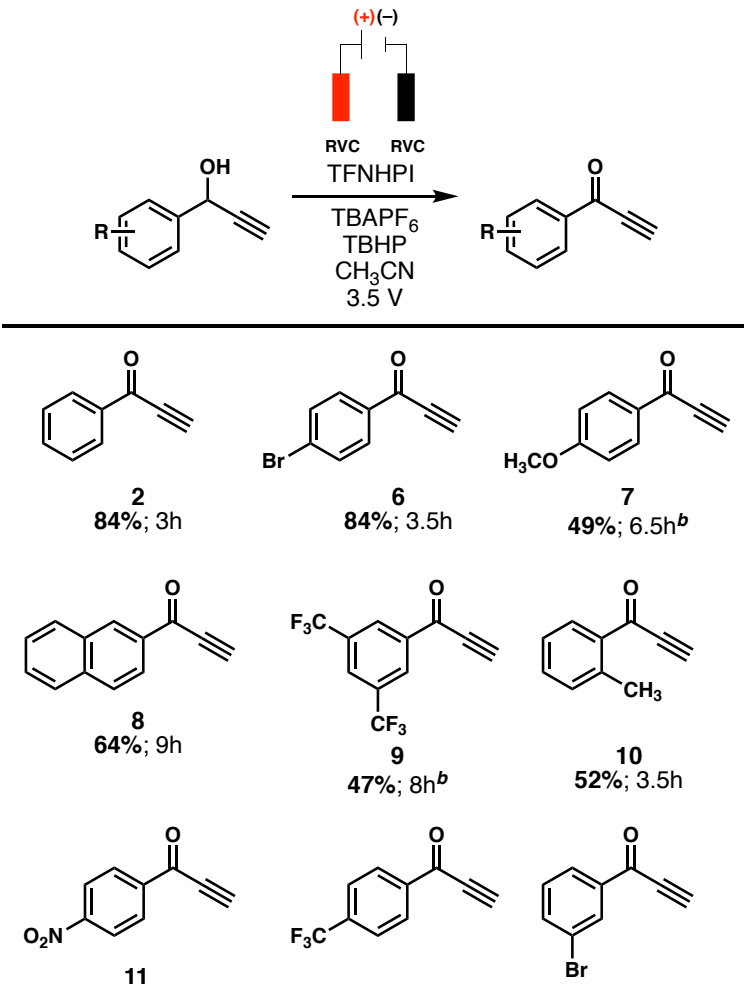

$18 \% ; 8 h^{b}$

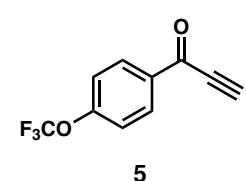

$73 \% ; 1.6 h^{b}$
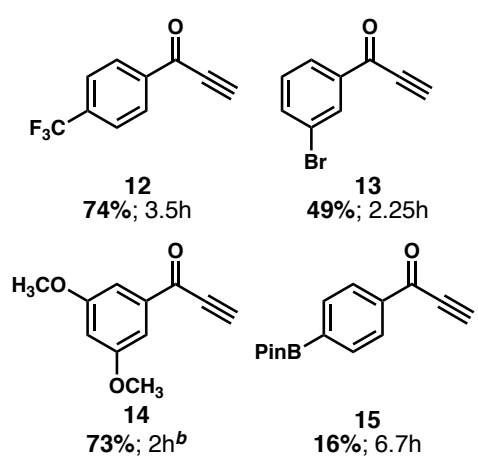

${ }^{a} 1.0 \mathrm{mmol}$ alcohol, isolated yield; $2.5 \mathrm{~mol} \%$ TFNHPI, $0.1 \mathrm{M}$ TBAPF $_{6}, 10.0$ equiv. $5.5 \mathrm{M}$ tert-butyl hydroperoxide in decane. ${ }^{b}$ Divided cell.

method described above provides a means to generate a variety of propargyl phenyl ketones in 16-84\% yield, including those that we could not oxidize at all under thermal conditions (e.g. $\mathbf{5}$, vide supra). Moreover, the electrochemical oxidations can be routinely conducted on multi-gram scale in inexpensive, readily available glassware or in disposable falcon tubes while open to ambient air and moisture. No exotic preparations or precautions need be taken, and reactions could be conveniently monitored by conventional thin-layer chromatography.

We hypothesize that the electrochemical oxidation of propargyl alcohols to ketones proceeds as shown in Scheme 3. Oxidation of TFNHPI at the anode, coupled to loss of proton generates a highly reactive phthalimido $N$-oxyl (PINO) radical. Generation of the PINO radical is also possible in the presence of exogenous bases, albeit at less positive potentials..$^{2 x}$ The PINO radical can abstract a hydrogen atom from the hydroxyl-bearing carbon on the alcohol substrate to generate a carbon centered 
radical. combination of the carbon radical with electrochemically generated tert-butyl peroxy radical $\left(t \mathrm{Bu}-\mathrm{OO}^{\circ}\right)$ would be expected to yield a peroxy hemiketal. Spontaneous decomposition of the peroxy hemiketal yields the desired ketone product.

Scheme 3. Proposed Oxidation Mechanism with TFNHPI as an Electrochemical Mediator.

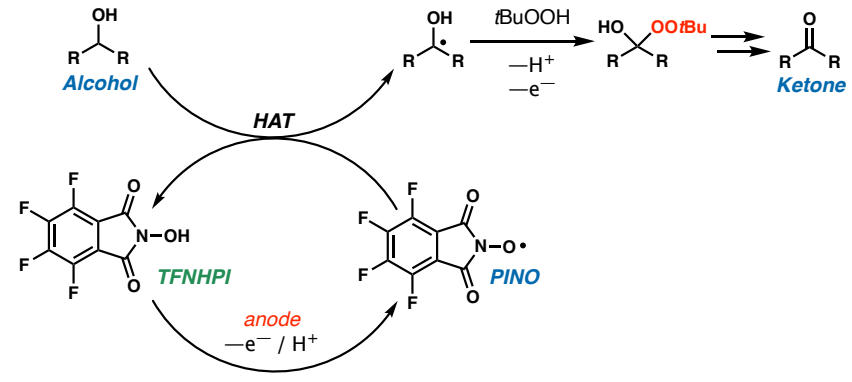

The electro-oxidation protocol detailed above and in Scheme 3 may be used to facilitate the expedient synthesis of several classes of phenolic natural products such as the pauciflorols, the ampelopsins, the caraphenols, the parthenocissins, and the quadrangularins.$^{35}$ As a demonstration of utility, we completed the five-step syntheses of pauciflorol $\mathrm{F}^{36}$ and isopauciflorol $\mathrm{F}$ enabled by the oxidation of alcohols $\mathbf{1 8}$ and $\mathbf{2 3}$ as shown in Scheme 4. We prepared alcohols 18 and 23 in $94 \%$ and $83 \%$ yield, respectively, by the addition of a lithium acetylide to methoxybenzaldehydes in cold ethyl ether. The alcohol 18 was oxidized to the ynone 19 in $68 \%$ yield on multi-gram scale utilizing our optimized electrochemical method in a divided electrolysis cell, with the addition of pyridine as an exogenous base. ${ }^{37}$ Ynone 19 was converted to the $\alpha, \beta$-unsaturated ketone 20 by a reductive Stille-type coupling with an aryl halide under the action of low-valent palladium and tri- $n$-butyltin hydride in $89 \%$ yield. $^{38}$ Subsequent Nazarov ${ }^{39}$ cyclization of enone 20 results in the trans-disubstituted ketone 21 in $46 \%$ yield. Global deprotection results in pauciflorol $\mathrm{F}(\mathbf{2 2})$ in five steps and $23 \%$ overall yield from commercial starting materials. A similar sequence efficiently transforms the alcohol $\mathbf{2 3}$ into isopauciflorol F (24) (see Scheme 4), including the electrochemical oxidation of 23 in $65 \%$ yield. Thus, utilizing the oxidation protocol we have developed, a single researcher can generate gram quantities of pauciflorol F (22) and isopauciflorol F (24) in a single week. ${ }^{40}$ While we were disappointed to find that pauciflorol $\mathrm{F}$ (22) and isopauciflorol $F(24)$ exhibited no significant activity in the NCI60 panel (despite prior reports of promising anti-cancer potential), further studies exploring biological activity of the pauciflorols is ongoing.

In summary, the TFNHPI mediator allows for an array of new electrochemical transformations that have been otherwise difficult or impossible to realize using conventional thermal chemistries. This electrochemical platform is being used as a springboard in our laboratories for new opportunities in complex molecule synthesis. Some of these transformations include allylic oxidations/peroxidations, direct oxygenations of fully saturated $s p^{3}$-carbon centers, transient generation of unstable dienes in Diels-Alder chemistry, and various nitrogen-based chemistries which are all being studied for their applications in total syntheses of terpenoid and alkaloid natural products. These methods, along with the accompanying total syntheses, will be disclosed in due course.

Scheme 4. An Electrochemically-Enabled Synthesis of the Pauciflorols. ${ }^{a}$

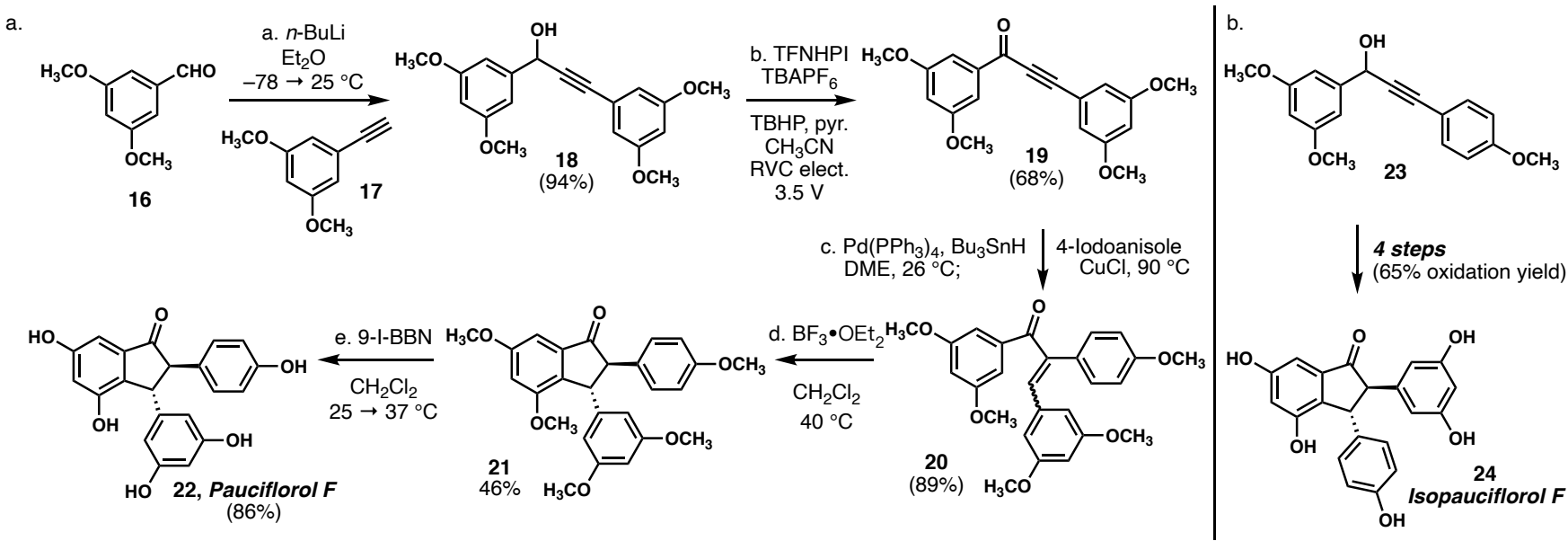

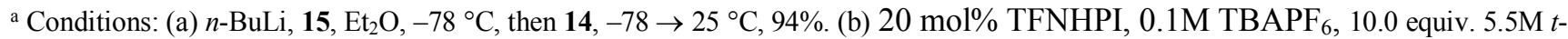

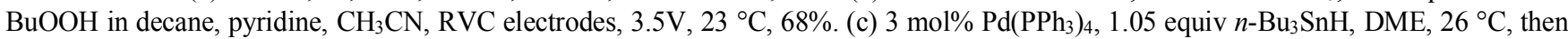
1.1 equiv 4-iodoanisole, 0.83 equiv $\mathrm{CuCl}, 90{ }^{\circ} \mathrm{C}, 89 \%$. (d) $\mathrm{BF}_{3}{ }^{\circ} \mathrm{OEt}_{2}, \mathrm{CH}_{2} \mathrm{Cl}_{2}, 40{ }^{\circ} \mathrm{C}, 46 \%$. (e) 9-I-BBN, $\mathrm{CH}_{2} \mathrm{Cl}_{2}, 25 \rightarrow 37{ }^{\circ} \mathrm{C}, 86 \%$.

\section{ASSOCIATED CONTENT}

\section{Supporting Information}

Detailed experimental procedures, photographs of experimental apparatus, characterization data for all compounds, cyclic voltammograms, and X-ray crystallographic data.

The Supporting Information is available free of charge on the ACS Publications website.

\section{AUTHOR INFORMATION}

\section{Corresponding Author}

* joelr@udel.edu

*wchain@udel.edu

\section{Author Contributions}

\$These authors contributed equally.

\section{ACKNOWLEDGMENT}


The University of Delaware (UD), and the National Institutes of Health (P20 GM104316) are gratefully acknowledged for financial support. JR also acknowledges support from the U.S. Department of Energy, Office of Science, Office of Basic Energy Sciences EPSCoR and Catalysis programs under Award Number DESC-0001234. Spectral data was acquired at UD on instruments obtained with the assistance of NSF and NIH funding (NSF CHE0421224, CHE0840401, CHE1229234, CHE1048367; NIH S10 OD025185, S10 OD016267-01, S10 RR026962-01, P20 GM104316, P30 GM110758, S10 OD025185).

\section{REFERENCES}

1. Tojo, G.; Fernández, M., Oxidation of Alcohols to Aldehydes and Ketones. Springer: New York, 2006.

2. Bowden, K.; Heilbron, I. M.; Jones, E. R. H.; Weedon, B. C. L., J. Chem. Soc. (Resumed) 1946.

3. Collins, J. C.; Hess, W. W., Org. Syn. 1972, 52.

4. (a) See ref. 2 (b) Nanko, M.; Inaba, Y.; Sekine, K.; Mikami, K., Helv. Chim. Acta 2021, 104. (c) González-Granda, S.; MéndezSánchez, D.; Lavandera, I.; Gotor-Fernández, V., ChemCatChem 2019, 12, 520-527. (d) Chen, V. Y.; Kwon, O., Angew. Chem. Int. Ed. Engl. 2021, 60, 8874-8881.

5. (a) Shi, F.; Luo, S. W.; Tao, Z. L.; He, L.; Yu, J.; Tu, S. J.; Gong, L. Z., Org. Lett. 2011, 13, 4680-4683. (b) See ref. 4c

6. Ge, G. C.; Mo, D. L.; Ding, C. H.; Dai, L. X.; Hou, X. L., Org. Lett. 2012, 14, 5756-5759.

7. Liao, S.; Liu, J.; Yan, L.; Liu, Q.; Chen, G.; Ma, L., RSC Advances 2020, 10, 37014-37022.

8. Lipp, A.; Selt, M.; Ferenc, D.; Schollmeyer, D.; Waldvogel, S. R.; Opatz, T., Org. Lett. 2019, 21, 1828-1831.

9. Nakamura, H.; Yasui, K.; Kanda, Y.; Baran, P. S., J. Am. Chem. Soc. 2019, 141, 1494-1497.

10. Zhang, H.; Tang, R.; Shi, X.; Xie, L.; Wu, J., Chinese J. Org. Chem. 2019, 39.

11. Lin, Y.; Malins, L. R., Chem. Sci. 2020, 11, 10752-10758.

12. Okamoto, K.; Chiba, K., Org. Lett. 2020, 22, 3613-3617.

13. Yano, K.; Itoh, T.; Nokami, T., Carbohydr. Res. 2020, 492, 108018.

14. Wang, B.; Liu, Z.; Tong, Z.; Gao, B.; Ding, H., Angew. Chem. Int. Ed. Engl. 2021, 60, 14892-14896.

15. (a) Rosen, B. R.; Werner, E. W.; O'Brien, A. G.; Baran, P. S., J. Am. Chem. Soc. 2014, 136, 5571-5574. (b) Horn, E. J.; Rosen, B. R.; Chen, Y.; Tang, J.; Chen, K.; Eastgate, M. D.; Baran, P. S., Nature 2016, 533, 77-81. (c) Kawamata, Y.; Yan, M.; Liu, Z.; Bao, D. H.; Chen, J.; Starr, J. T.; Baran, P. S., J. Am. Chem. Soc. 2017, 139, 74487451. (d) Li, C.; Kawamata, Y.; Nakamura, H.; Vantourout, J. C.; Liu, Z.; Hou, Q.; Bao, D.; Starr, J. T.; Chen, J.; Yan, M.; Baran, P. S., Angew. Chem. Int. Ed. Engl. 2017, 56, 13088-13093. (e) Yan, M.; Kawamata, Y.; Baran, P. S., Chem. Rev. 2017, 117, 13230-13319. (f) Yan, M.; Kawamata, Y.; Baran, P. S., Angew. Chem. Int. Ed. Engl. 2018, 57, 4149-4155. (g) Kawamata, Y.; Vantourout, J. C.; Hickey, D. P.; Bai, P.; Chen, L.; Hou, Q.; Qiao, W.; Barman, K.; Edwards, M. A.; Garrido-Castro, A. F.; deGruyter, J. N.; Nakamura, H.; Knouse, K.; Qin, C.; Clay, K. J.; Bao, D.; Li, C.; Starr, J. T.; GarciaIrizarry, C.; Sach, N.; White, H. S.; Neurock, M.; Minteer, S. D.; Baran, P. S., J. Am. Chem. Soc. 2019, 141, 6392-6402. (h) Nakamura, H.; Yasui, K.; Kanda, Y.; Baran, P. S., J. Am. Chem. Soc. 2019, 141, 1494-1497. (i) Peters, B. K.; Rodriguez, K. X.; Reisberg, S. H.; Beil, S. B.; Hickey, D. P.; Kawamata, Y.; Collins, M.; Starr, J.; Chen, L.; Udyavara, S.; Klunder, K.; Gorey, T. J.; Anderson, S. L.; Neurock, M.; Minteer, S. D.; Baran, P. S., Science 2019, 363, 838-845. (j) Xiang, J.; Shang, M.; Kawamata, Y.; Lundberg, H.; Reisberg, S. H.; Chen, M.; Mykhailiuk, P.; Beutner, G.; Collins, M. R.; Davies, A.; Del Bel, M.; Gallego, G. M.; Spangler, J. E.; Starr, J.; Yang, S.; Blackmond, D. G.; Baran, P. S., Nature 2019, 573, 398-402. (k) Chen, L.; Barton, L. M.; Vantourout, J. C.; Xu, Y.; Chu, C.; Johnson, E. C.; Sabatini, J. J.; Baran, P. S., Org. Proc. Res. Dev. 2020. (1) Hu, P.; Peters, B. K.; Malapit, C. A.; Vantourout, J. C.; Wang, P.; Li, J.; Mele, L.; Echeverria, P. G.; Minteer, S. D.; Baran, P. S., J. Am. Chem. Soc. 2020, 142, 20979-20986. (m) arton, L. M.; Chen, L.;
Blackmond, D. G.; Baran, P. S., Proc. Natl. Acad. Sci. U. S. A. 2021 118. (n) Gao, Y.; Hill, D. E.; Hao, W.; McNicholas, B. J.; Vantourout, J. C.; Hadt, R. G.; Reisman, S. E.; Blackmond, D. G.; Baran, P. S., J. Am. Chem. Soc. 2021, 143, 9478-9488. (o) Gnaim, S.; Takahira, Y.; Wilke, H. R.; Yao, Z.; Li, J.; Delbrayelle, D.; Echeverria, P. G.; Vantourout, J. C.; Baran, P. S., Nat. Chem. 2021, 13, 367-372. (p) Saito, M.; Kawamata, Y.; Meanwell, M.; Navratil, R.; Chiodi, D.; Carlson, E.; Hu, P.; Chen, L.; Udyavara, S.; Kingston, C.; Tanwar, M.; Tyagi, S.; McKillican, B. P.; Gichinga, M. G.; Schmidt, M. A.; Eastgate, M. D.; Lamberto, M.; He, C.; Tang, T.; Malapit, C. A.; Sigman, M. S.; Minteer, S. D.; Neurock, M.; Baran, P. S., J. Am. Chem. Soc. 2021, 143, 7859-7867. (q) Zhang, H. J.; Chen, L.; Oderinde, M. S.; Edwards, J. T.; Kawamata, Y.; Baran, P. S., Angew. Chem. Int. Ed. Engl. 2021, 60, 20700-20705.

16. (a) Lennox, A. J. J.; Goes, S. L.; Webster, M. P.; Koolman, H. F.; Djuric, S. W.; Stahl, S. S., J. Am. Chem. Soc. 2018, 140, 1122711231. (b) Nutting, J. E.; Rafiee, M.; Stahl, S. S., Chem. Rev. 2018, 118, 4834-4885. (c) Rafiee, M.; Konz, Z. M.; Graaf, M. D.; Koolman, H. F.; Stahl, S. S., ACS Catalysis 2018, 8, 6738-6744. (d) Rafiee, M.; Wang, F.; Hruszkewycz, D. P.; Stahl, S. S., J. Am. Chem. Soc. 2018, 140, 22-25. (e) Wang, F.; Rafiee, M.; Stahl, S. S., Angew. Chem. Int. Ed. Engl. 2018, 57, 6686-6690. (f) Das, A.; Nutting, J. E.; Stahl, S. S., Chem. Sci. 2019, 10, 7542-7548. (g) Rafiee, M.; Alherech, M.; Karlen, S. D.; Stahl, S. S., J. Am. Chem. Soc. 2019, 141, 1526615276. (h) Wang, F.; Stahl, S. S., Angew. Chem. Int. Ed. Engl. 2019, 58, 6385-6390. (i) Anson, C. W.; Stahl, S. S., Chem. Rev. 2020, 120, 3749-3786. (j) Bruns, D. L.; Musaev, D. G.; Stahl, S. S., J. Am. Chem. Soc. 2020, 142, 19678-19688. (k) Gerken, J. B.; Anson, C. W.; Preger, Y.; Symons, P. G.; Genders, J. D.; Qiu, Y.; Li, W.; Root, T. W.; Stahl, S. S., Adv. Energy Mat. 2020, 10. (1) Gerken, J. B.; Stamoulis, A.; Suh, S. E.; Fischer, N. D.; Kim, Y. J.; Guzei, I. A.; Stahl, S. S., Chem. Commun. (Camb.) 2020, 56, 1199-1202. (m) Wang, F.; Gerken, J. B.; Bates, D. M.; Kim, Y. J.; Stahl, S. S., J. Am. Chem. Soc. 2020, 142, 12349-12356. (n) Wang, F.; Stahl, S. S., Acc. Chem. Res. 2020, 53, 561-574. (o) Goes, S. L.; Mayer, M. N.; Nutting, J. E.; Hoober-Burkhardt, L. E.; Stahl, S. S.; Rafiee, M., J. Chem. Educ. 2021, 98, 600-606. (p) Nutting, J. E.; Gerken, J. B.; Stamoulis, A. G.; Bruns, D. L.; Stahl, S. S., J. Org. Chem. 2021. (q) Wang, F.; Li, W.; Wang, R.; Guo, T.; Sheng, H.; Fu, H.-C.; Stahl, S. S.; Jin, S., Joule 2021, 5, 149-165. (r) Wang, F.; Sheng, H.; Li, W.; Gerken, J. B.; Jin, S.; Stahl, S. S., ACS Energy Lett. 2021, 6, 1533-1539. (s) Zhong, X.; Hoque, M. A.; Graaf, M. D.; Harper, K. C.; Wang, F.; Genders, J. D.; Stahl, S. S., Org. Proc. Res. Dev. 2021.

17. (a) Little, R. D.; Moeller, K. D., Chem. Rev. 2018, 118, 44834484. (b) Moeller, K. D., Chem. Rev. 2018, 118, 4817-4833. (c) Francke, R.; Gonzalez, L.; Little, R. D.; Moeller, K. D., Electrons, Electrodes, and the Transformation of Organic Molecules. In Surface and Interface Science, 2020; Vol. 10. (d) Wu, T.; Moeller, K. D., Angew. Chem. Int. Ed. Engl. 2021, 60, 12883-12890.

18. Wiebe, A.; Gieshoff, T.; Mohle, S.; Rodrigo, E.; Zirbes, M.; Waldvogel, S. R., Angew. Chem. Int. Ed. Engl. 2018, 57, 5594-5619.

19. Nutting, J. E.; Gerken, J. B.; Stamoulis, A. G.; Bruns, D. L.; Stahl, S. S., J. Org. Chem. 2021.

20. Wu, W.; Decker, G. E.; Weaver, A. E.; Arnoff, A. I.; Bloch, E. D.; Rosenthal, J., ACS Cent. Sci. 2021, 7, 1427-1433.

21. Antonio, A. M.; Rosenthal, J.; Bloch, E. D., J. Am. Chem. Soc. 2019, 141, 11383-11387.

22. (a) Rand, D. A. J., J. Solid State Electrochem. 2011, 15, 15791622. (b) Horn, E. J.; Rosen, B. R.; Baran, P. S., ACS Cent. Sci. 2016, 2, 302-308. (c) Kawamata, Y.; Baran, P. S., Joule 2020, 4, 701-704. (d) Kenis, P. J. A., Electrochem. Soc. Interface 2020, 29, 41-42.

23. Ghosh, M.; Shinde, V. S.; Rueping, M., Beilstein J. Org. Chem. 2019, 15, 2710-2746.

24. Semmelhack, M. F.; Chou, C. S.; Cortes, D. A., J. Am. Chem. Soc. 1983, 105, 4492-4494.

25. Tamirat, A. G.; Guan, X.; Liu, J.; Luo, J.; Xia, Y., Chem. Soc. Rev. 2020, 49, 7454-7478.

26. Horn, E. J.; Rosen, B. R.; Chen, Y.; Tang, J.; Chen, K.; Eastgate, M. D.; Baran, P. S., Nature 2016, 533, 77-81.

27. Recupero, F.; Punta, C., Chem. Rev. 2007, 107, 3800-3842. 
28. Yang, C.; Farmer, L. A.; Pratt, D. A.; Maldonado, S.; Stephenson, C. R. J., J. Am. Chem. Soc. 2021, 143, 10324-10332.

29. Coe, P. L.; Croll, B. T.; Patrick, C. R., Tetrahedron 1967, 23, 505-508.

30. Kalviri, H. A.; Petten, C. F.; Kerton, F. M., Chem. Commun. (Camb.) 2009, 5171-5173.

31. Petten, C. F.; Kalviri, H. A.; Kerton, F. M., Sustainable Chemical Processes 2015, 3.

32. Kalviri, H. A.; Kerton, F. M., Adv. Synth. Catal. 2011, 353, 3178-3186

33. A brief coulombic study was reported that suggested TFNHPI could mediate electrochemical oxidative processes, but no preparation of TFNHPI or practical oxidation protocols employing TFNHPI were described. See: Gorgy, K.; Lepretre, J. C.; Saint-Aman, E.; Einhorn, C.; Einhorn, J.; Marcadal, C.; Pierre, J. L., Electrochimica Acta 1998, 44, 385-393.

34. (a) Barton, D. H. R.; Le Gloahec, V. r. N.; Patin, H.; Launay, F., New J. Chem. 1998, 22, 559-563. (b) Barton, D. H. R.; Le Gloahec, V. r. N.; Patin, H., New J. Chem. 1998, 22, 565-568. (c) Barton, D. H. R.; Le Gloahec, V. r. N., Tetrahedron 1998, 54, $15457-$ 15468.

35. (a) Kulanthaivel, P.; Janzen, W. P.; Ballas, L. M.; Jiang, J. B.; Hu, C. Q.; Darges, J. W.; Seldin, J. C.; Cofield, D. J.; Adams, L. M., Planta Med. 1995, 61, 41-44. (b) Adesanya, S. A.; Nia, R.; Martin,
M.-T.; Boukamcha, N.; Montagnac, A.; Païs, M., J. Nat. Prod. 1999, 62, 1694-1695. (c) Luo, H.-F.; Zhang, L.-P.; Hu, C.-Q., Tetrahedron 2001, 57, 4849-4854. (d) Zhong, C.; Zhu, J.; Chang, J.; Sun, X., Tetrahedron Lett. 2011, 52, 2815-2817. (e) Jin, Q.; Han, X. H.; Hong, S. S.; Lee, C.; Choe, S.; Lee, D.; Kim, Y.; Hong, J. T.; Lee, M. K.; Hwang, B. Y., Bioorg. Med. Chem. Lett. 2012, 22, 973-976.

36. For selected prior syntheses of pauciflorols, see: (a) Snyder, S. A.; Zografos, A. L.; Lin, Y. Angew. Chem. Int. Ed. Engl. 2007, 46, 8186-8191. (b) Jeffrey, J. L.; Sarpong, R. Tetrahedron Lett. 2009, 50, 1969-1972. (c) Jeffrey, J. L.; Sarpong, R. Org. Lett. 2009, 11, $5450-5453$.

37. Annunziatini, C.; Gerini, M. F.; Lanzalunga, O.; Lucarini, M., J. Org. Chem. 2004, 69, 3431-3438.

38. Cordovilla, C.; Bartolomé, C.; Martínez-Ilarduya, J. M.; Espinet, P., ACS Catalysis 2015, 5, 3040-3053.

39. Vinogradov, M. G.; Turova, O. V.; Zlotin, S. G., Org. Biomol. Chem. 2017, 15, 8245-8269.

40 . We expect to complete an array of similar natural products for future biological investigations based on this platform. 


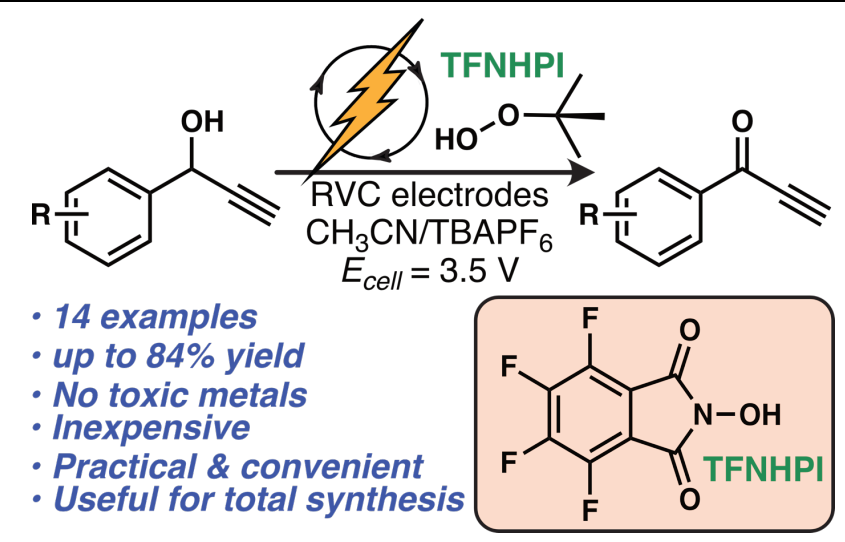

Tojo, G.; Fernández, M., Oxidation of Alcohols to Aldehydes and Ketones. Springer: New York, 2006.

Bowden, K.; Heilbron, I. M.; Jones, E. R. H.; Weedon, B. C. L., J. Chem. Soc. (Resumed) 1946.

Collins, J. C.; Hess, W. W., Org. Syn. 1972, 52.

(a) See ref. 2 (b) Nanko, M.; Inaba, Y.; Sekine, K.; Mikami, K., Helv. Chim. Acta 2021, 104. (c) González-Granda, S.; Méndez-Sánchez, D.; Lavandera, I.; Gotor-Fernández, V., ChemCatChem 2019, 12, 520-527. (d) Chen, V. Y.; Kwon, O., Angew. Chem. Int. Ed. Engl. 2021, 60, 8874-8881.

(a) Shi, F.; Luo, S. W.; Tao, Z. L.; He, L.; Yu, J.; Tu, S. J.; Gong, L. Z., Org. Lett. 2011, 13, 4680-4683. (b) See ref. 4c

Ge, G. C.; Mo, D. L.; Ding, C. H.; Dai, L. X.; Hou, X. L., Org. Lett. 2012, 14, 5756-5759.

Liao, S.; Liu, J.; Yan, L.; Liu, Q.; Chen, G.; Ma, L., RSC Advances 2020, 10, 37014-37022.

${ }^{*}$ Lipp, A.; Selt, M.; Ferenc, D.; Schollmeyer, D.; Waldvogel, S. R.; Opatz, T., Org. Lett. 2019, 21 , $1828-1831$.

- Nakamura, H.; Yasui, K.; Kanda, Y.; Baran, P. S., J. Am. Chem. Soc. 2019, 141, 1494-1497.

${ }^{10}$ Zhang, H.; Tang, R.; Shi, X.; Xie, L.; Wu, J., Chinese J. Org. Chem. 2019, 39.

Lin, Y.; Malins, L. R., Chem. Sci. 2020, 11, 10752-10758.

Okamoto, K.; Chiba, K., Org. Lett. 2020, 22, 3613-3617.

Yano, K.; Itoh, T.; Nokami, T., Carbohydr. Res. 2020, 492, 108018.

Wang, B.; Liu, Z.; Tong, Z.; Gao, B.; Ding, H., Angew. Chem. Int. Ed. Engl. 2021, 60, 14892-14896.

s (a) Rosen, B. R.; Werner, E. W.; O'Brien, A. G.; Baran, P. S., J. Am. Chem. Soc. 2014, 136, 5571-5574. (b) Horn, E. J.; Rosen, B. R.; Chen, Y.; Tang, J.; Chen, K.; Eastgate, M. D.; Baran, P. S., Nature 2016, 533, 77-81. (c) Kawamata, Y.; Yan, M.; Liu, Z.; Bao, D. H.; Chen, J.; Starr, J. T.; Baran, P. S., J. Am. Chem. Soc. 2017, 139, 7448-7451. (d) Li, C.; Kawamata, Y.; Nakamura, H.; Vantourout, J. C.; Liu, Z.; Hou, Q.; Bao, D.; Starr, J. T.; Chen, J.; Yan, M.; Baran, P. S., Angew. Chem. Int. Ed. Engl. 2017, 56, 13088-13093. (e) Yan, M.; Kawamata, Y.; Baran, P. S., Chem. Rev. 2017, 117, 13230-13319. (f) Yan, M.; Kawamata, Y.; Baran, P. S., Angew. Chem. Int. Ed. Engl. 2018, 57, 4149-4155. (g) Kawamata, Y.; Vantourout, J. C.; Hickey, D. P.; Bai, P.; Chen, L.; Hou, Q.; Qiao, W.; Barman, K.; Edwards, M. A.; Garrido-Castro, A. F.; deGruyter, J. N.; Nakamura, H.; Knouse, K.; Qin, C.; Clay, K. J.; Bao, D.; Li, C.; Starr, J. T.; Garcia-Irizarry, C.; Sach, N.; White, H. S.; Neurock, M.; Minteer, S. D.; Baran, P. S., J. Am. Chem. Soc. 2019, 141, 6392-6402. (h) Nakamura, H.; Yasui, K.; Kanda, Y.; Baran, P. S., J. Am. Chem. Soc. 2019, 141, 1494-1497. (i) Peters, B. K.; Rodriguez, K. X.; Reisberg, S. H.; Beil, S. B.; Hickey, D. P.; Kawamata, Y.; Collins, M.; Starr, J.; Chen, L.; Udyavara, S.; Klunder, K.; Gorey, T. J.; Anderson, S. L.; Neurock, M.; Minteer, S. D.; Baran, P. S., Science 2019, 363, 838-845. (j) Xiang, J.; Shang, M.; Kawamata, Y.; Lundberg, H.; Reisberg, S. H.; Chen, M.; Mykhailiuk, P.; Beutner, G.; Collins, M. R.; Davies, A.; Del Bel, M.; Gallego, G. M.; Spangler, J. E.; Starr, J.; Yang, S.; Blackmond, D. G.; Baran, P. S., Nature 2019, 573, 398-402. (k) Chen, L.; Barton, L. M.; Vantourout, J. C.; Xu, Y.; Chu, C.; Johnson, E. C.; Sabatini, J. J.; Baran, P. S., Org. Proc. Res. Dev. 2020. (l) Hu, P.; Peters, B. K.; Malapit, C. A.; Vantourout, J. C.; Wang, P.; Li, J.; Mele, L.; Echeverria, P. G.; Minteer, S. D.; Baran, P. S., J. Am. Chem. Soc. 2020, 142, 20979-20986. (m) arton, L. M.; Chen, L.; Blackmond, D. G.; Baran, P. S., Proc. Natl. Acad. Sci. U. S. A. 2021, 118. (n) Gao, Y.; Hill, D. E.; Hao, W.; McNicholas, B. J.; Vantourout, J. C.; Hadt, R. G.; Reisman, S. E.; Blackmond, D. G.; Baran, P. S., J. Am. Chem. Soc. 2021, 143,9478-9488. (o) Gnaim, S.; Takahira, Y.; Wilke, H. R.; Yao, Z.; Li, J.; Delbrayelle, D.; Echeverria, P. G.; Vantourout, J. C.; Baran, P. S., Nat. Chem. 2021, 13, 367-372. (p) Saito, M.; Kawamata, Y.; Meanwell, M.; Navratil, R.; Chiodi, D.; Carlson, E.; Hu, P.; Chen, L.; Udyavara, S.; Kingston, C.; Tanwar, M.; Tyagi, S.; McKillican, B. P.; Gichinga, M. G.; Schmidt, M. A.; Eastgate, M. D.; Lamberto, M.; He, C.; Tang, T.; Malapit, C. A.; Sigman, M. S.; Minteer, S. D.; Neurock, M.; Baran, P. S., J. Am. Chem. Soc. 2021, 143, 7859-7867. (q) Zhang, H. J.; Chen, L.; Oderinde, M. S.; Edwards, J. T.; Kawamata, Y.; Baran, P. S., Angew. Chem. Int. Ed. Engl. 2021, 60, 20700-20705.

${ }^{16}$ (a) Lennox, A. J. J.; Goes, S. L.; Webster, M. P.; Koolman, H. F.; Djuric, S. W.; Stahl, S. S., J. Am. Chem. Soc. 2018, 140, 11227-11231. (b) Nutting, J. E.; Rafiee, M.; Stahl, S. S., Chem. Rev. 2018, 118, 4834-4885. (c) Rafiee, M.; Konz, Z. M.; Graaf, 
M. D.; Koolman, H. F.; Stahl, S. S., ACS Catalysis 2018, 8, 6738-6744. (d) Rafiee, M.; Wang, F.; Hruszkewycz, D. P.; Stahl, S. S., J. Am. Chem. Soc. 2018, 140, 22-25. (e) Wang, F.; Rafiee, M.; Stahl, S. S., Angew. Chem. Int. Ed. Engl. 2018, 57, 66866690. (f) Das, A.; Nutting, J. E.; Stahl, S. S., Chem. Sci. 2019, 10, 7542-7548. (g) Rafiee, M.; Alherech, M.; Karlen, S. D.; Stahl, S. S., J. Am. Chem. Soc. 2019, 141, 15266-15276. (h) Wang, F.; Stahl, S. S., Angew. Chem. Int. Ed. Engl. 2019, 58, 6385-6390. (i) Anson, C. W.; Stahl, S. S., Chem. Rev. 2020, 120, 3749-3786. (j) Bruns, D. L.; Musaev, D. G.; Stahl, S. S., J. Am. Chem. Soc. 2020, 142, 19678-19688. (k) Gerken, J. B.; Anson, C. W.; Preger, Y.; Symons, P. G.; Genders, J. D.; Qiu, Y.; Li, W.; Root, T. W.; Stahl, S. S., Adv. Energy Mat. 2020, 10. (1) Gerken, J. B.; Stamoulis, A.; Suh, S. E.; Fischer, N. D.; Kim, Y. J.; Guzei, I. A.; Stahl, S. S., Chem. Commun. (Camb.) 2020, 56, 1199-1202. (m) Wang, F.; Gerken, J. B.; Bates, D. M.; Kim, Y. J.; Stahl, S. S., J. Am. Chem. Soc. 2020, 142, 12349-12356. (n) Wang, F.; Stahl, S. S., Acc. Chem. Res. 2020, 53, 561574. (o) Goes, S. L.; Mayer, M. N.; Nutting, J. E.; Hoober-Burkhardt, L. E.; Stahl, S. S.; Rafiee, M., J. Chem. Educ. 2021, 98, 600-606. (p) Nutting, J. E.; Gerken, J. B.; Stamoulis, A. G.; Bruns, D. L.; Stahl, S. S., J. Org. Chem. 2021. (q) Wang, F.; Li, W.; Wang, R.; Guo, T.; Sheng, H.; Fu, H.-C.; Stahl, S. S.; Jin, S., Joule 2021, 5, 149-165. (r) Wang, F.; Sheng, H.; Li, W.; Gerken, J. B.; Jin, S.; Stahl, S. S., ACS Energy Lett. 2021, 6, 1533-1539. (s) Zhong, X.; Hoque, M. A.; Graaf, M. D.; Harper, K. C.; Wang, F.; Genders, J. D.; Stahl, S. S., Org. Proc. Res. Dev. 2021.

(a) Little, R. D.; Moeller, K. D., Chem. Rev. 2018, 118, 4483-4484. (b) Moeller, K. D., Chem. Rev. 2018, 118, 4817-4833. (c) Francke, R.; Gonzalez, L.; Little, R. D.; Moeller, K. D., Electrons, Electrodes, and the Transformation of Organic Molecules. In Surface and Interface Science, 2020; Vol. 10. (d) Wu, T.; Moeller, K. D., Angew. Chem. Int. Ed. Engl. 2021, 60, 12883-12890.

${ }^{18}$ Wiebe, A.; Gieshoff, T.; Mohle, S.; Rodrigo, E.; Zirbes, M.; Waldvogel, S. R., Angew. Chem. Int. Ed. Engl. 2018, 57, 5594-5619.

${ }^{19}$ Nutting, J. E.; Gerken, J. B.; Stamoulis, A. G.; Bruns, D. L.; Stahl, S. S., J. Org. Chem. 2021.

${ }^{20} \mathrm{Wu}, \mathrm{W} . ;$ Decker, G. E.; Weaver, A. E.; Arnoff, A. I.; Bloch, E. D.; Rosenthal, J., ACS Cent. Sci. 2021, 7, 1427-1433.

"Antonio, A. M.; Rosenthal, J.; Bloch, E. D., J. Am. Chem. Soc. 2019, 141, 11383-11387.

(a) Rand, D. A. J., J. Solid State Electrochem. 2011, 15, 1579-1622. (b) Horn, E. J.; Rosen, B. R.; Baran, P. S., ACS Cent. Sci. 2016, 2, 302-308. (c) Kawamata, Y.; Baran, P. S., Joule 2020, 4, 701-704. (d) Kenis, P. J. A., Electrochem. Soc. Interface 2020, $29,41-42$.

${ }_{23}$ Ghosh, M.; Shinde, V. S.; Rueping, M., Beilstein J. Org. Chem. 2019, 15, 2710-2746.

${ }^{24}$ Semmelhack, M. F.; Chou, C. S.; Cortes, D. A., J. Am. Chem. Soc. 1983, 105, 4492-4494.

«s Tamirat, A. G.; Guan, X.; Liu, J.; Luo, J.; Xia, Y., Chem. Soc. Rev. 2020, 49, 7454-7478.

${ }^{26}$ Horn, E. J.; Rosen, B. R.; Chen, Y.; Tang, J.; Chen, K.; Eastgate, M. D.; Baran, P. S., Nature 2016, 533, 77-81.

Recupero, F.; Punta, C., Chem. Rev. 2007, 107, 3800-3842.

${ }^{28}$ Yang, C.; Farmer, L. A.; Pratt, D. A.; Maldonado, S.; Stephenson, C. R. J., J. Am. Chem. Soc. 2021, 143, 10324-10332.

Coe, P. L.; Croll, B. T.; Patrick, C. R., Tetrahedron 1967, 23, 505-508.

${ }^{2}$ Kalviri, H. A.; Petten, C. F.; Kerton, F. M., Chem. Commun. (Camb.) 2009, 5171-5173.

Petten, C. F.; Kalviri, H. A.; Kerton, F. M., Sustainable Chemical Processes 2015, 3.

Kalviri, H. A.; Kerton, F. M., Adv. Synth. Catal. 2011, 353, 3178-3186.

${ }_{33}$ A brief coulombic study was reported that suggested TFNHPI could mediate electrochemical oxidative processes, but no preparation of TFNHPI or practical oxidation protocols employing TFNHPI were described. See: Gorgy, K.; Lepretre, J. C.; Saint-Aman, E.; Einhorn, C.; Einhorn, J.; Marcadal, C.; Pierre, J. L., Electrochimica Acta 1998, 44, 385-393.

${ }^{3}$ (a) Barton, D. H. R.; Le Gloahec, V. r. N.; Patin, H.; Launay, F., New J. Chem. 1998, 22, 559-563. (b) Barton, D. H. R.; Le Gloahec, V. r. N.; Patin, H., New J. Chem. 1998, 22, 565-568. (c) Barton, D. H. R.; Le Gloahec, V. r. N., Tetrahedron 1998, 54, 15457-15468.

ss (a) Kulanthaivel, P.; Janzen, W. P.; Ballas, L. M.; Jiang, J. B.; Hu, C. Q.; Darges, J. W.; Seldin, J. C.; Cofield, D. J.; Adams, L. M., Planta Med. 1995, 61, 41-44. (b) Adesanya, S. A.; Nia, R.; Martin, M.-T.; Boukamcha, N.; Montagnac, A.; Païs, M., J. Nat. Prod. 1999, 62, 1694-1695. (c) Luo, H.-F.; Zhang, L.-P.; Hu, C.-Q., Tetrahedron 2001, 57, 4849-4854. (d) Zhong, C.; Zhu, J.; Chang, J.; Sun, X., Tetrahedron Lett. 2011, 52, 2815-2817. (e) Jin, Q.; Han, X. H.; Hong, S. S.; Lee, C.; Choe, S.; Lee, D.; Kim, Y.; Hong, J. T.; Lee, M. K.; Hwang, B. Y., Bioorg. Med. Chem. Lett. 2012, 22, 973-976.

${ }^{36}$ For selected prior syntheses of pauciflorols, see: (a) Snyder, S. A.; Zografos, A. L.; Lin, Y. Angew. Chem. Int. Ed. Engl. 2007, 46, 8186-8191. (b) Jeffrey, J. L.; Sarpong, R. Tetrahedron Lett. 2009, 50, 1969-1972. (c) Jeffrey, J. L.; Sarpong, R. Org. Lett. 2009, 11, 5450-5453.

${ }^{37}$ Annunziatini, C.; Gerini, M. F.; Lanzalunga, O.; Lucarini, M., J. Org. Chem. 2004, 69, 3431-3438.

${ }^{3}$ Cordovilla, C.; Bartolomé, C.; Martínez-Ilarduya, J. M.; Espinet, P., ACS Catalysis 2015, 5, 3040-3053.

${ }^{3}$ Vinogradov, M. G.; Turova, O. V.; Zlotin, S. G., Org. Biomol. Chem. 2017, 15, 8245-8269.

${ }^{4}$ We expect to complete an array of similar natural products for future biological investigations based on this platform. 